\title{
Apoptosis in Granulosa cells during follicular atresia: relationship with steroids and insulin-like growth factors
}

\author{
Yuan Song YU*, Hong Shu SUI, Zheng Bin HAN, Wei LI, Ming Jiu LUO, Jing He TAN** \\ Laboratory of Animal Reproduction and Embryology College of Animal Sciences and Veterinary Medicine, Shandong \\ Agricultural University, Taian, Shandong 271018, China
}

\begin{abstract}
It is well known that during mammalian ovarian follicular development, the majority of follicles undergo atresia at various stages of their development. However, the mechanisms controlling this selection process remain unknown. In this study, we investigated apoptosis in granulosa cells during goat follicular atresia by terminal deoxynucleotidyl transferase-mediated dUTP nick end labeling (TUNEL). The changes in the levels of steroids, insulin-like growth factors (IGFs) and IGF receptors were studied by radioimmunoassay (RIA) and semi-quantitative reverse transcription-PCR. We found that the percentage of apoptotic granulosa cells in the atretic (A) follicles was significantly higher than that in the slightly atretic (SA) and healthy $(\mathrm{H})$ follicles. The level of estradiol and the ratio of estradiol to progesterone in $\mathrm{H}$ follicles were significantly higher than those in A follicles. On the other hand, the level of progesterone was not significantly different among these follicle types. We also found that the level of IGF-I in H follicles was higher than in SA and A follicles, whereas the amount of IGF-II did not vary significantly. The expression of IGF receptor also decreased in A follicles as compared to that in $\mathrm{H}$ and SA follicles. These results suggested that estradiol and IGF-I might be involved in controlling apoptosis in granulosa cells during follicular atresia.
\end{abstract}

Keywords: apoptosis, ovarian follicle, steroids, IGFs, atresia.

\section{INTRODUCTION}

During mammalian ovarian follicular development, only limited numbers of follicles are selected for ovulation, whereas the rest undergo atresia at various stages of development [1]. Despite the overwhelming evidence for follicular atresia in the ovary, the cellular and molecular mechanisms underlying this phenomenon remain poorly understood. Previous studies indicate that the death of granulosa cells (GC) triggers atresia of the follicles [2-3], and death of the GC itself by apoptosis was found to occur in chicken, mouse [2], cow [4], ewe [5] and pig [6-7]. Although it has been suggested that alterations in steroidogenesis might be involved in the initiation of follicular atresia [4, 8-9], the exact pattern of steroid hormone during atresia has yet to be established. It has been shown that Insulin-like growth factors (IGFs) could block apoptosis induced by dexamethasone in various cell types. It is thus possible that IGFs play an important role in

\footnotetext{
${ }^{*}$ Present address: College of life science, University of Beijing, Beijing, China.

${ }^{* *}$ Correspondence: Jing He TAN,

Tel: (86) 0538 8249616, Fax: (86) 0538 8241419;

Email: tanjh@sdau.edu.cn
}

regulating follicular development and granulosa cell apoptosis [10-11]. Available data related to the expression of IGF-I, IGF-II (rat [12], mouse [13], human [14]) and type-1 IGFR (rat [10]) in the ovary are controversial. Very little is known about the expression of IGFs and their receptors in ruminant species. Therefore, the regulating mechanism of follicular atresia may be different among different species. In this study we systematically studied the relationship between the levels of IGFs and steroids and granulosa cell apoptosis in goat ovary. Our results indicate that significant apoptosis occurs in atretic, but not healthy follicles. Apoptosis of granulosa cells is related to the imbalance between estradiol and progesterone in the follicular fluid. The level of IGF-I, but not IGF-II, is the crucial factor in deciding whether a follicle will mature or undergo atresia.

\section{MATERIALS AND METHODS}

\section{Isolation of follicles and granulosa cells}

Goat ovaries were collected from a local abattoir and brought to the laboratory in saline at $30-35{ }^{\circ} \mathrm{C}$ within $2 \mathrm{~h}$ after euthanasia. Follicles with diameters of 2-5 $\mathrm{mm}$ were excised from the ovary and were classified using a stereomicroscope into healthy $(\mathrm{H})$, slightly 
atretic (SA) and atretic (A) groups according to a previous report [15]. Briefly, the $H$ follicles had vascularized (pink or red) theca interna and clear amber follicular fluid (FF) with no debris; the SA follicles had rough and off-white theca interna with fewer but larger blood vessels and thick FF with much debris; and the A follicles had gray theca interna with no blood vessels and flocculent FF with many dark gobbets.

Follicles were cut in half and the interior walls were gently scraped with an inoculating loop to remove GC. The GC were harvested by centrifuging the FF at $400 \mathrm{~g}$ for $10 \mathrm{~min}$. Cells were then washed three times with PBS. The GC pellets were re-suspended in PBS and smeared for detection of apoptosis by TUNEL. FF Supernatant was centrifuged at $2000 \mathrm{~g}$ to remove debris and stored at $-20^{\circ} \mathrm{C}$ before RIA for steroids and IGFs.

\section{Preparation of smears and detection of apoptotic cells}

Granulosa cells were fixed by combining equal volumes of granulosa-cell suspension and 4\% paraformaldehyde; after $20 \mathrm{~min}$, cells were washed. A small drop of the suspension was then smeared on a slide and allowed to dry. Apoptosis in granulosa cells was detected by terminal deoxynucleotidyl transferase-mediated dUTP nick end labeling (TUNEL) using a cell apoptosis detection kit (Boehringer Mannheim, Indianapolis, IN USA). The procedures were as follows: cells were 1) fixed in $4 \%$ paraformaldehyde in PBS for $1 \mathrm{~h}$ at room temperature; 2) rinsed 3 times with PBS and incubated with $0.3 \%$ $\mathrm{H}_{2} \mathrm{O}_{2}$ in methanol for $1 \mathrm{~h}$ to quench endogenous peroxidase activity; 3 ) rinsed 3 times in PBS and treated with $0.1 \%$ Triton $X-100$ at $4{ }^{\circ} \mathrm{C}$ for $2 \mathrm{~min}$; 4) rinsed 3 times in PBS and incubated with TUNEL reaction mixture $(50 \mu \mathrm{l})$ in a humidified chamber at $37^{\circ} \mathrm{C}$ for $\left.1 \mathrm{~h} ; 5\right)$ washed 3 times in PBS and incubated with $50 \mu$ l Converter-POD (Peroxidase, Boehringer Mannheim) in a humidified chamber at $37^{\circ} \mathrm{C}$ for $30 \mathrm{~min} ; 6$ ) rinsed 3 times with PBS and exposed to the DAB (3, 3 '-diaminobezidine tetrahydrochloride) -substrate solution for color development in a dark chamber at room temperature for 3 to $5 \mathrm{~min}$; and 7) washed in PBS, dehydrated in ethanol, cleared in xylene, and mounted with balsam. For negative controls, slides were incubated with $50 \mu$ label solution (without terminal transferase) instead of TUNEL reaction mixture. Smears were observed under a light microscope and percentages of apoptotic cells were calculated from 500 cells on each smear.

\section{Reverse transcription-PCR}

Twenty follicles from each category were homogenized and treated with Trizol (Gibco BRL, Gaithersbrug, MD) and total RNA was extracted according to the manufacturer's instructions. The RNA was re-suspended in DEPC- $\mathrm{dH}_{2} \mathrm{O}$ and digested with PQ1 DNase I (Promega Corp., Madison, WI). Glyceraldehyde-3-phosphate dehydrogenase (GAPDH) was used as a control for the quality of cDNA preparations. Since DNA or cDNA sequences for goat GAPDH, IGF-I, IGF-II were not available from GenBank, we identified fully conserved sequences among human, mouse and ovine. The sense and antisense primers used for RT-PCR were: GAPDH, 5'-ACCACAGTCCATGCCATCAC-3'and 5'-TCCACCACCCTGTTGCTGTA-3' for amplification of a 452-bp fragment; IGF-I, 5'-GACAGGAATCGTGGATGAGTG-3' and 5'-AACAGGTAACTCGTGACGAGC-3' for amplification of a $277 \mathrm{bp}$ fragment; IGF-II, 5'-CGTGGCATCGTGGAAGAGTGT-3' and 5-'GGTGACTCTTGGCCTCTCTGA-3' for amplification of a 270bp fragment;
IGFR，5'-ACTGACCTCATGCGCATGTGCTGG-3' and 5'CTCGTTCTTGCGGCCCCCGTTCAT-3' for amplification of a 345 bp fragment, respectively. The RNA samples were reverse-transcribed and PCR-amplified using Takara BcaBEST RNA PCR kit (Takara Biotechniques, Dalian, China) according to the manufacturer's protocol. The RT reaction was performed at $65^{\circ} \mathrm{C}$ for $1 \mathrm{~min}, 30^{\circ} \mathrm{C}$ for $5 \mathrm{~min}, 65^{\circ} \mathrm{C}$ for $30 \mathrm{~min}, 98^{\circ} \mathrm{C}$ for $5 \mathrm{~min}$ and $5^{\circ} \mathrm{C}$ for $5 \mathrm{~min}$. The amplification of IGF-I and IGFR cDNA was done for 35 cycles at $94^{\circ} \mathrm{C}$ for $2.5 \mathrm{~min}, 59^{\circ} \mathrm{C}$ for $30 \mathrm{sec}$ and $72^{\circ} \mathrm{C}$ for $1 \mathrm{~min}$. IGF-II and GAPDH cDNA amplification was performed for 28 cycles at $94^{\circ} \mathrm{C}$ for $2.5 \mathrm{~min}, 60^{\circ} \mathrm{C}$ for $30 \mathrm{sec}$ and $72^{\circ} \mathrm{C}$ for $1 \mathrm{~min}$. The accuracy of this method was checked by regression analysis and the amplification coefficient was determined. The relative expression of mRNA for each gene of interest was calculated using a formula devised by Prelle et al [20]. To check for the specificity of RT-PCR, three controls were tested for genomic DNA contamination: 1) RNA samples directly amplified without reverse transcription, 2) reverse transcription done without adding reverse transcriptase, followed by PCR amplification. 3) RNA samples replaced by DEPC- $\mathrm{dH}_{2} \mathrm{O}$ in RTPCR. RT-PCR reactions were carried out only after ascertaining that all 3 controls were free of DNA contamination.

\section{Radioimmunoassay}

Concentrations of progesterone (P4) and estradiol (E2) in follicular fluid in unextracted samples were determined by direct radioimmunoassay (RIA) using a commercial kit (Jiuding Biotechniques Ltd, Tianjin, China), which has been validated for goat samples [17]. A blank culture medium assay showed no cross-reactivity and values below the limit of sensitivity $(0.1 \mathrm{ng} / \mathrm{ml}$ for P4 and $1 \mathrm{pg} / \mathrm{ml}$ for E2). The intra- and inter-assay CVs were $7.2 \%$ and $6.9 \%, 8.0 \%$ and $7.7 \%$, respectively. IGF-I and IGF-II were also detected by RIA. Samples were acid-ethanol extract-concentrated [18-19] and their concentrations were determined using a commercial kit (Jiuding biotechniques Ltd). The limits of sensitivity were $0.1 \mathrm{ng} / \mathrm{ml}$ and $0.1 \mathrm{ng} / \mathrm{ml}$, respectively, and the intra- and inter-assay $\mathrm{CVs}$ were $<10 \%$ and $<15 \%$, and $<10 \%$ and $<15 \%$, respectively.

\section{Statistical Analysis}

For each treatment, at least three replicates were run. Statistical analyses were carried out by ANOVA. Differences between treatment groups were evaluated by the Duncan multiple comparison test. Data are expressed as mean $\pm \mathrm{SE}$ and $\mathrm{P}<0.05$ was considered significant.

\section{RESULTS AND DISCUSSION}

\section{Apoptosis in granulosa cells of follicles at different stages of atresia}

During mammalian follicle development, most follicles undergo atresia at different stages, a process critical to allow only a specific number of follicles to mature in each mammalian species. It is believed that, during atresia, cell death occurs in granulosa cells. Due to the difficulties in the isolation of granulosa cells, the nature of this cell death still is not clearly defined. Hughes and Gorospe [2] reported an oligonucleosomal ladder pattern of genomic DNA 


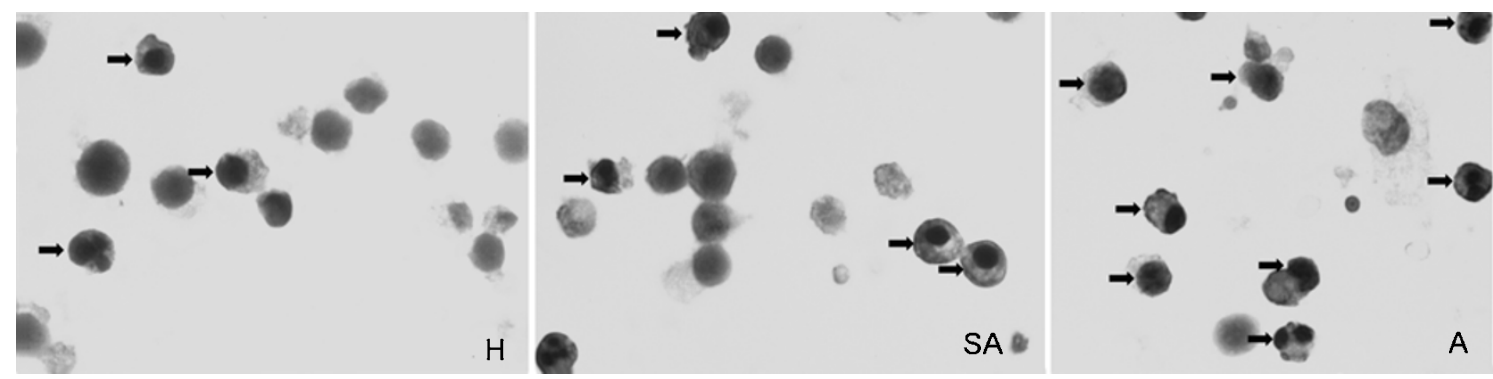

Fig. 1 Photomicrographs $(\times 1000)$ of granulosa cell smears from healthy $(H)$, slightly atretic $(S A)$ and atretic $(A)$ follicles after TUNEL staining. TUNEL positive cells (arrows) are sparse in $\mathrm{H}$ follicles but numerous in A follicles.

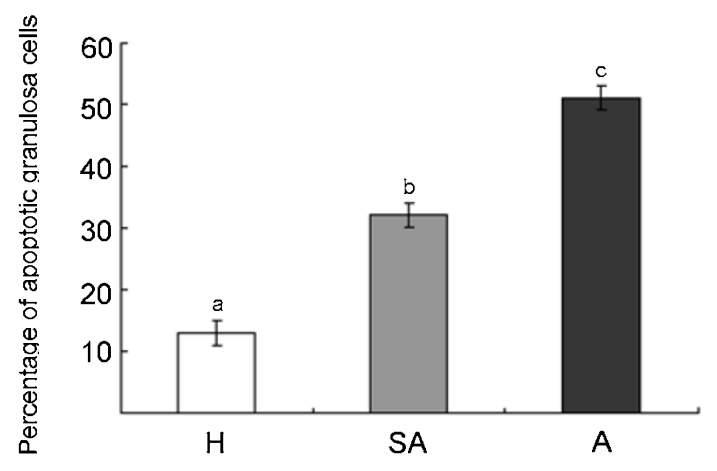

Fig. 2 Percentages of apoptotic granulosa cells in atretic (A), slightly atretic (SA) and healthy $(\mathrm{H})$ follicles. Differences between values marked with different letters are significant $(\mathrm{P}<0.05)$.

fragments in atretic rat follicles. However, a similar DNA fragment pattern was also shown in the healthy follicles, although the ladder was fainter. On the other hand, Palumbo and Yeh [20] were unable to confirm apoptotic granulosa cells in the healthy follicles of the same species. Other studies in sheep $[4,21]$ and bovine [22] also demonstrated granulosa cell apoptosis in the healthy follicles. To verify the difference in apoptosis between atretic and healthy follicles, we employed a more definitive protocol to determine genomic DNA fragmentation using the TUNEL assay. We isolated granulosa cells from freshly procured goat follicles and staged them according to [15]. Granulosa cells were collected and cell smears were prepared on glass slides processed for TUNEL staining. We found that TUNEL positive apoptotic cells were sparse $(13 \pm 2 \%)$ in granulosa cells of $\mathrm{H}$ follicles (Fig. 1H). The number of TUNEL positive cells was significantly higher in SA follicles (32 $\pm 2 \%$ ) (Fig.1SA). On the other hand, around half of granulosa cells $(51 \pm 2 \%)$ from A follicles underwent apoptosis as defined by the TUNEL assay (Fig. 1A). Forty-five follicles from 9 goats were tested and com- parisons by ANOVA revealed significant difference among the three groups ( $\mathrm{P}<0.01$, Fig. 2$)$. Therefore, our TUNEL assay showed clear differences in apoptotic cells during follicular atresia.

\section{Changes in P4 and E2 levels in follicular fluid dur- ing atresia}

Studies showed that follicular atresia was related to the production of steroids. It has been suggested that the balance between estradiol and progesterone may be a good predictor of whether a follicle will proceed to maturity or to undergo atresia [21, 23-24]. We, therefore, measured the concentration of E2 and P4 in FF and found that the level of estradiol is significantly lower in atretic follicles than that in healthy follicles. The level of progesterone, on the other hand, was higher in astretic follicles, which resulted in a significant change in the ratio of E2/P4: $>1$ in healthy follicles and $<1$ in atretic follicles (Tab. 1). These results suggest that an imbalance between E2 and P4 in follicular fluid is involved in the initiation of granulosa cell apoptosis and hence follicular atresia.

\section{Changes in IGF expression during follicle atresia}

IGFs are some of the most prominent apoptosis inhibitory cytokines and their regulated expression in various tissues play a pivotal role in regulating cellular homeostasis [25]. Expression of IGF-I and IGF-II in the ovary is different among different species. In the rat, ovarian IGF-I gene expression was restricted to granulosa cells of the healthy, but not atretic or luteinized, antral follicles [12]. In the mouse, IGF-I transcripts increased in healthy follicles, but decreased as a function of atresia [13]. In human, however, the level of IGF-I was similar in both the estrogen and androgen dominant follicles, while the level of IGF-II was higher in the estrogen dominant follicles [14]. Reports on the expression pattern of IGFs in the ruminant ovary are controversial. Yuan et al [26] 
Tab. 1 Concentrations of E2 and P4 and the E2/P4 ratio in the follicular fluid from follicles with different degrees of atresia

\begin{tabular}{lccc}
\hline Type of follicles & $\begin{array}{c}\text { Concentration of E2 } \\
(\mathrm{ng} / \mathrm{ml})\end{array}$ & $\begin{array}{c}\text { Concentration of P4 } \\
(\mathrm{ng} / \mathrm{ml})\end{array}$ & E2/P4 \\
\hline Healthy & $0.2 \pm 0.04^{\mathrm{a}}$ & $0.17 \pm 0.06^{\mathrm{a}}$ & $3.9 \pm 2.5^{\mathrm{a}}$ \\
Slightly atretic & $0.07 \pm 0.01^{\mathrm{a}}$ & $1.2 \pm 0.6^{\mathrm{a}}$ & $0.2 \pm 0.2^{\mathrm{b}}$ \\
Atretic & $0.05 \pm 0.01^{\mathrm{b}}$ & $1.7 \pm 1.1^{\mathrm{a}}$ & $0.08 \pm 0.06^{\mathrm{b}}$ \\
\hline
\end{tabular}

Differences between values marked with different superscript letters in the same column are significant $(\mathrm{p}<0.05)$.
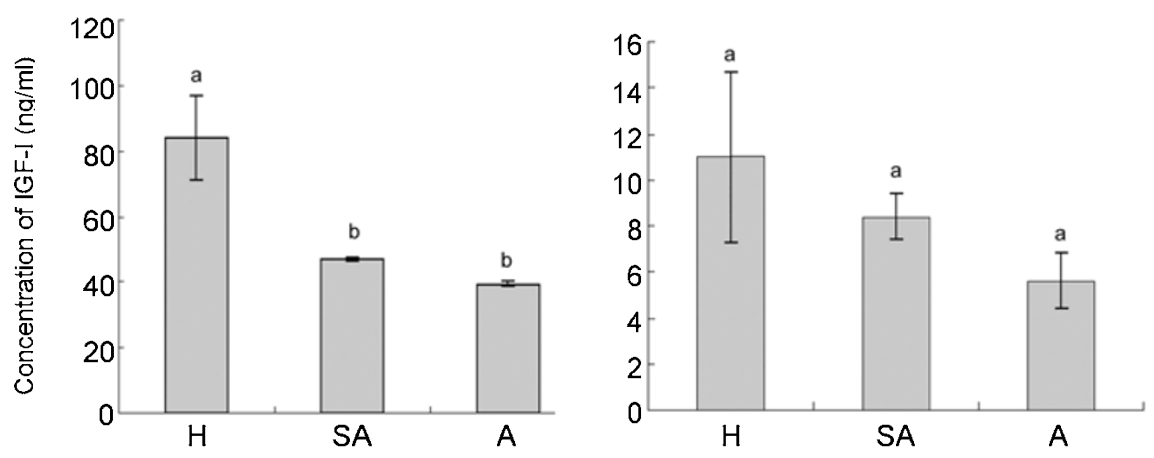

Fig. 3 Concentrations of IGF-I (A) and IGF-II (B) in the follicular fluid from healthy (H), slightly atretic (SA) and atretic (A) follicles. Differences between values marked with different letters are significant $(\mathrm{P}<0.05)$.

proved mRNA expression of both IGF-I and IGF-II in bovine granulosa cells. Ginther et al [27] reported an increased level of IGF-I in the largest follicles of bovine. However, Armstrong et al [28] were unable to confirm the expression of IGF-I mRNA in bovine granulosa cells, but they found IGF-II expression in the theca cells instead.

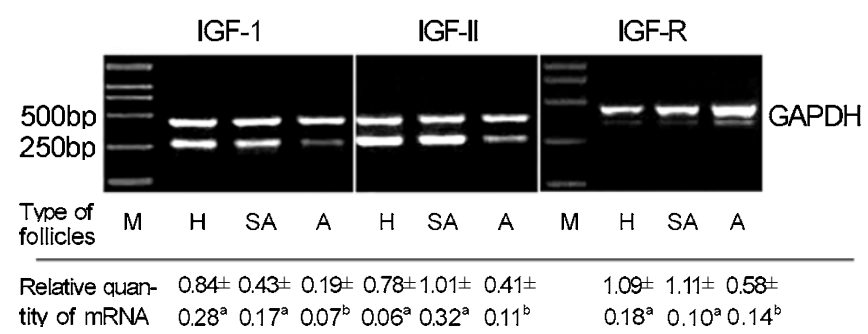

Fig. 4 Expression of IGF-I, IGF-II and IGFR mRNAs in healthy $(\mathrm{H})$, slightly atretic $(\mathrm{SA})$ and atretic $(\mathrm{A})$ follicles. Standard marker (M) shows 500 and 250bp bands. In other lanes, the bands below GAPDH are mRNAs of IGFs or IGFRs. The mRNA levels were normalized to the GAPDH signals, and the relative quantity of mRNA expression is expressed as a fraction of Max OD. Differences between values marked with different superscript letters are significant $(\mathrm{P}<0.05)$.
We examined the levels of IGF-I and IGF-II by RIA and found that the level of IGF-I was significantly higher than that of IGF-II in all three follicle types. The concentration of IGF-I in $\mathrm{H}$ follicles $(83.5 \pm 12.9 \mathrm{ng} / \mathrm{ml})$ was significantly higher $(\mathrm{P}<0.05)$ than that in $\mathrm{SA}(46.9 \pm 0.3 \mathrm{ng} / \mathrm{ml})$ and $\mathrm{A}$ follicles $(39.3 \pm 0.9 \mathrm{ng} / \mathrm{ml})($ Fig. $3 \mathrm{~A})$. However, the concentration of IGF-II did not change significantly $(\mathrm{P}>$ 0.05 ) during follicle atresia (Fig. 3B). To further verify this result, we examined the level of IGF messages in granulosa cells by semi-quantitative RT-PCR. Our results demonstrate that the relative quantity (Max OD) of IGF-I mRNA expression decreased with follicular atresia (Fig. 4). Besides, our previous study showed that IGF-I significantly reduced the percentage of apoptotic granulosa cells cultured in vitro [17].

The action of IGFs was mainly mediated via the type-1 IGF receptor [29]. In bovine, the level of type-1 IGFR was related to the degree of follicular atresia [14], but in the rat, type-1 IGFR was consistently expressed in follicles at different stages and degrees of atresia [10]. We showed in this study that, as in bovine, the expression of type-1 IGFR mRNA decreased with follicular atresia (Fig. 4). Therefore, it seems that, in the goat, it is IGF-I 
that plays a more important role in the control of follicular atresia.

In conclusion, our results indicate that (i) significant apoptosis occurs during follicle atresia; (ii) apoptosis of granulosa cells is related to the imbalance between estradiol and progesterone in the follicular fluid; and (iii) the level of IGF-I, but not IGF-II, is the crucial factor in deciding whether a follicle matures or undergoes atresia in the goat ovary.

\section{AKCNOWLEDGMENT}

This work was supported by the National Natural Science Foundation of China (No. 30070556) and the Major State Basic Research Development Program of China (No. G200016107).

Received, Apr 1, 2004

Revised, July 30, 2004

Accepted, July 31, 2004

\section{REFERENCES}

1 Byskov AG. Follicular atresia. In: Jones RE editor, The Vertebrate Ovary. Plenum Press, New York. 1978; p533-562.

2 Hughes FM Jr, Gorospe WC. Biochemical identification of apoptosis (programmed cell death) in granulosa cells: evidence for a potential mechanism underlying follicular atresia. Endocrinology 1991; 129: 2415-22.

3 Rajakoski E. The ovarian follicular system in sexually mature heifers with special reference to season, cyclical and left-right variation. Acta Endocrinol Suppl 1996; 52:1-68.

4 Jolly PD, Tisdall DJ, Heath DA, Lun S, McNatty KP. Apoptosis in bovine granulosa cells in relation to steroid synthesis, cyclic adenosine 3',5'-monophosphate response to follicle-stimulating hormone and luteinizing hormone, and follicular atresia. Biol Reprod 1994; 51:934-944.

5 Murdoch WJ. Programmed cell death in preovulatory ovine follicles. Biol Reprod 1995; 53:8-12.

6 Miki S, Noboru M, Yoshihiro K, et al. Ultrastructural changes in granulose cells in porcine antral follicles undergoing atresia indicate apoptotic cell death. J Reprod Dev 1998; 44:7-14.

7 Liu ZH, Yue KZ, Ma SF, Sun XS, Tan JH. Effects of pregnant mare serum gonadotropin (eCG) on follicle development and granulosa-cell apoptosis in the pig. Theriogenology 2003; 59: 775-785.

8 Hsueh AJ, Billig H, Tsafriri A. Ovarian follicle atresia: a hormonally controlled apoptotic process. Endocr Rev 1994; 15:707-24.

9 Rosenfeld CS, Wagner JS, Roberts RM, Lubahn DB. Intraovarian actions of oestrogen. Reproduction 2001; 122: 215-26.

10 deMoura MD, Chamoun D, Resnick CE, Adashi EY. Insulinlike growth factor (IGF)-I stimulates IGF-I and type 1 IGF receptor expression in cultured rat granulosa cells: autocrine regulation of the intrafollicular IGF-I system. Endocrine 2000; 13: 103-10.

11 Armstrong DG, McEvoy TG, Baxter G, et al. Effect of dietary energy and protein on bovine follicular dynamics and embryo production in vitro: associations with the ovarian insulin-like growth factor system. Biol Reprod 2001; 64:1624-32.

12 Poretsky L, Cataldo NA, Rosenwaks Z, Giudie LC. The insulinrelated ovarian regulatory system in health and disease. Endocr Rev 1999; 20:535-82.

13 Wandji SA, Wood TL, Crawford J, Levison SW, Hammond JM. Expression of mouse ovarian insulin growth factor system components during follicular development and atresia. Endocrinology 1998; 139:5205-14.

14 El-Roeiy A, Chen X, Roberts VJ, et al. Expression of the genes encoding the insulin-like growth factors (IGF-I and II), the IGF and insulin receptors, and IGF-binding proteins-1-6 and the localization of their gene products in normal and polycystic ovary syndrome ovaries. J Clin Endocrinol Metab 1994; 78:1488-96.

15 Yang MY, Rajamahendran R. Morphological and biochemical identification of apoptosis in small, medium, and large bovine follicles and the effects of follicle-stimulating hormone and insulin-like growth factor-I on spontaneous apoptosis in cultured bovine granulosa cells. Biol Reprod 2000; 62:1209-17.

16 Prelle K, Stojkovic M, Boxhammer K, et al. Insulin-like growth factor I (IGF-I) and long R(3)IGF-I differently affect development and messenger ribonucleic acid abundance for IGF-binding proteins and type I IGF receptors in in vitro produced bovine embryos. Endocrinology 2001; 142:1309-16.

$17 \mathrm{Yu} \mathrm{Y,} \mathrm{Li} \mathrm{W,} \mathrm{Han} \mathrm{ZB,} \mathrm{et} \mathrm{al.} \mathrm{The} \mathrm{effect} \mathrm{of} \mathrm{follicle-stimulating}$ hormone on follicular development, granulosa cell apoptosis and steriodogenesis and its mediation by insulin-like growth factor-1 in the goat ovary. Theriogenology 2003; 60:1691-704.

18 Khalid M, Haresign W, Luck MR. Secretion of IGF-1 by ovine granulosa cells: effects of growth hormone and follicle stimulating hormone. Anim Reprod Sci 2000; 58: 261-72.

19 Spicer LJ, Chamberlain CS. Production of insulin-like growth factor-I by granulosa cells but not thecal cells is hormonally responsive in cattle. J Anim Sci 2000; 78: 2919-26.

20 Palumbo A, Yeh J. In situ localization of apoptosis in the rat ovary during follicular atresia. Biol Reprod 1994; 51:888-95.

21 Jolly PD, Smith PR, Heath DA, et al. Morphological evidence of apoptosis and the prevalence of apoptotic versus mitotic cells in the membrana granulosa of ovarian follicles during spontaneous and induced atresia in ewes. Biol Reprod 1997; 56: 837-46.

22 Blondin P, Sirard MA. Oocyte and follicular morphology as determining characteristics for developmental competence in bovine oocytes. Mol Reprod Dev 1995; 41: 54-62.

23 Rosales-Torres AM, Avalos-Rodriguez A, Vergara-Onofre M, et al. Multiparametric study of atresia in ewe antral follicles: histology, flow cytometry, internucleosomal DNA fragmentation, and lysosomal enzyme activities in granulosa cells and follicular fluid. Mol Reprod Dev 2000; 55: 270-81.

24 Huet C, Monget P, Pisselet C, Monniaux D. Changes in extracellular matrix components and steroidogenic enzymes during growth and atresia of antral ovarian follicles in the sheep. Biol Reprod 1997; 56: 1025-34.

25 Yin DL, Pu L, Pei G. Antisense oligonucleotide to insulin-like growth factor II induces apoptosis in human ovarian cancer AO cell line. Cell Res. 1998; 8:159-65.

26 Yuan W, Bao B, Garverick HA, Youngquist RS, Lucy MC. Follicular dominance in cattle is associated with divergent patterns of ovarian gene expression for insulin-like growth factor (IGF)-I, IGF-II, and IGF binding protein-2 in dominant and subordinate 
follicles. Domest Anim Endocrinol 1998; 15: 55-63.

27 Ginther OJ, Bergfelt DR, Beg MA, Kot K. Effect of LH on circulating oestradiol and follicular fluid factor concentrations during follicle deviation in cattle. Reproduction 2001; 122: 10310 .

28 Armstrong DG, Gutierrez CG, Baxter G, et al. Expression of
mRNA encoding IGF-I, IGF-II and type 1 IGF receptor in bovine ovarian follicles. J Endocrinol 2000; 165:101-13.

29 Willis DS, Mason HD, Watson H, Franks S. Developmentally regulated responses of human granulosa cells to insulin-like growth factors (IGFs): IGF-I and IGF- II action mediated via the type1 IGF receptor. J Clin Endocrinol Metab 1998; 83: 1256-9. 